\title{
Case series report
}

\section{Interlay technique type 1 tympanoplasty, an alternative for closing large central tympanic membrane perforation}

\author{
Anton Budhi Darmawan \\ Department of Otorhinolaryngology Head and Neck Surgery, \\ Faculty of Medicine Jenderal Soedirman University/Prof. Dr. Margono Soekarjo Hospital, \\ Purwokerto
}

\begin{abstract}
Background: Type 1 tympanoplasty or myringoplasty is the most frequently performed procedure in the field of otology. Type 1 tympanoplasty is a surgical procedure to repair and only involves the restoration of the perforated tympanic membrane. There are three most accepted methods often used universally, namely underlay, overlay, and interlay. The interlay method is a relatively new method developed in 1992 for closing tympanic membrane perforation. This method has a high success rate of $96 \%$. Objective: To report the success of type 1 tympanoplasty with an interlay method to close large central tympanic membrane perforations at Margono Soekarjo District Hospital. Case Report: Reporting 3 cases of chronic tubotympanic suppurative otitis media with large central tympanic membrane perforation which were repaired by type 1 tympanoplasty using interlay method. Clinical Question: Does interlay method type 1 tympanoplasty performed on large central tympanic membrane perforation provide better result compared with other methods of type 1 tympanoplasty? Review Method: Studying the evidence-based literatures on type 1 tympanoplasty interlay methods through Cochrane, Pubmed, and Google Scholar databases. Based on the inclusion and exclusion criteria, three journals were relevant with the reported cases. Result: All three journals stated that interlay method type 1 tympanoplasty had high success rate in terms of closing the tympanic membrane perforation and diminishing air-bone gap. Conclusion: Type 1 Tympanoplasty interlay method could be used as an alternative for the closure of a large central tympanic membrane perforation.
\end{abstract}

Keywords: Chronic Tubotympanic Suppurative Otitis Media, large central tympanic membrane perforation, interlay tympanoplasty

\begin{abstract}
ABSTRAK
Latar belakang: Timpanoplasti tipe 1 atau miringoplasti merupakan prosedur di bidang otologi yang paling sering dilakukan. Timpanoplasti tipe 1 merupakan metode pembedahan yang bertujuan untuk memperbaiki, dan terbatas hanya di membran timpani. Terdapat tiga metode yang paling diterima dan sering digunakan secara universal, yaitu underlay, overlay, dan interlay. Metode interlay merupakan metode penambalan perforasi membran timpani yang relatif baru, dikembangkan pada tahun 1992. Metode ini mempunyai keberhasilan yang tinggi yaitu mencapai 96\%. Tujuan: Melaporkan keberhasilan timpanoplasti tipe 1 dengan metode interlay untuk penutupan perforasi membran timpani sentral besar di RSUD Margono Soekarjo. Laporan kasus: Dilaporkan 3 kasus otitis media supuratif kronik tipe tubotimpani dengan perforasi sentral besar, yang dilakukan timpanoplasti tipe 1 dengan metode interlay. Pertanyaan klinis: Apakah metode interlay timpanoplasti tipe 1 yang dilakukan pada perforasi membran timpani yang besar, dapat memberikan hasil yang lebih baik daripada metode lain timpanoplasti tipe 1? Telaah literatur: Telaah berbasis bukti mengenai timpanoplasti tipe 1 metode interlay melalui database Cochrane, Pubmed, dan Google Scholar. Berdasarkan kriteria inklusi dan ekslusi didapatkan tiga jurnal yang relevan dengan kasus yang dilaporkan. Hasil: Ketiga jurnal tersebut menyatakan bahwa timpanoplasti tipe 1 metode interlay mempunyai angka keberhasilan yang tinggi dalam hal penutupan perforasi membran timpani maupun mengurangi air-bone gap. Kesimpulan: Timpanoplasti tipe 1 metode interlay dapat digunakan sebagai alternatif untuk penutupan perforasi membran timpani sentral yang besar.
\end{abstract}


Kata kunci: Otitis media supuratif kronik tipe tubotimpani, perforasi membran timpani sentral besar, timpanoplasti metode interlay

Correspondence address: Anton Budhi Darmawan. Department of Otorhinolaryngology Head and Neck Surgery, Faculty of Medicine Jenderal Soedirman University/Prof. Dr. Margono Soekarjo Hospital, Purwokerto, Central Java. E-mail: ab.darmawan@gmail.com.

\section{INTRODUCTION}

Chronic Suppurative Otitis Media $(\mathrm{CSOM})$ is a chronic inflammation of the middle ear and mastoid cavity that is characterized by discharge from the middle ear through a perforated tympanic membrane. This disease causes a preventable hearing loss, and has a major impact on the social life of a person in the form of hearing disability particularly in developing countries. ${ }^{1,2}$ One type of CSOM is Tubotympanic (TT) or mucosal type or safe type. TT CSOM can be managed with tympanoplasty. Type 1 tympanoplasty or myringoplasty was first introduced by Berthold in 1878, using paper patch to seal the perforation, which was further popularized and developed by Wullstein and Zollner. In 1952 Wullstein used split thickness skin graft, in 1956, Zollner used fascia lata, and in 1958 Heerman started to use the fascia of musculus temporalis to close large central tympanic membrane perforation. ${ }^{3}$

Type 1 tympanoplasty or myringoplasty is the most frequently performed procedure in the field of otology. The main indication for tympanoplasty is repeated otorrhea and hearing loss. ${ }^{4}$ Type 1 tympanoplasty is a surgical procedure to repair and only involved the tympanic membrane, with the objective to improve hearing and ability to go swimming without safety ear plug.,

Type 1 tympanoplasty presented many advantages, among others no anterior canal wall blunting, no lateralization, no epithelial cyst formation, hearing improvement, and long term protection of middle ear damage by preventing ear bones pathology. Besides, it could prevent the migration of squamous epitheliums along the line of perforation and the possible consequences of iatrogenic cholesteatoma. ${ }^{6}$

It has been reported in the literatures that the final results of tympanoplasty in terms of uptake rate of the graft varies between $74 \%-97 \%$, depending on site and size of the perforation, technique used (endaural or postaural), surgical skill, experience of the practicing physician, type of graft, and graft method. ${ }^{4,7}$ Out of all these, the three most universally accepted techniques for graft positioning are "underlay," "overlay," and "interlay," and each one of these has its own advantages as well as disadvantages. The base of the three methods is graft positioning in tympanic remnant. In underlay method the graft is positioned in medial of mucous layer, in overlay method the graft is placed in lateral of fibrous layer after elevating tympanic membrane epithelial layer, and in interlay method the graft is placed between fibrous layer and mucous layer of tympanic membrane. ${ }^{5,8}$

The underlay method is generally applied for tympanic membrane perforation in posterior site. This method is the most frequently used universally, relatively easier to perform, lower chance of lateralization, less time to do, with a high success rate even in the hands of less skillful inexperienced surgeon.

The overlay method is used for tympanic membrane perforation in anterior site, subtotal perforation or revision of unsuccessful underlay method. The anterior and subtotal perforation of tympanic membrane often posed as the most difficult reconstructive tympanoplasty challenge for ENT specialists 
due to fewer vascularization compared to posterior tympanic membrane, and the presence of overhanging bone in the anterior ear canal that causes a limited tympanic membrane visualization. ${ }^{9}$

In interlay procedure, the graft is sandwiched between the canal wall and the remnant of tympanic membrane mucosa on one side, and tympanomeatal flap with squamous epithelial and fibrous layers on the other side. Thus, a sufficiently large raw area is available to serve as the vascular bed providing adequate blood supply to the graft. Hence, the average time of epithelization of graft is much shorter than other techniques, healing rate is superior and gain in hearing is more perceptible compared to other techniques. ${ }^{5,6}$

The procedure was started with an incision made about 3-5 $\mathrm{mm}$ from retroauricular sulcus, cutting through the skin, subcutis, and periosteum, started from linea temporalis to the tip of mastoid. ${ }^{6,10}$ Meatotomy was performed, followed by freshening the edge of tympanic membrane perforation. Incision of tympanomeatal flap at 12 hour and 6 hour, proceeded to half circle incision from inferior to superior starting from the tip of incision at 6 hour. ${ }^{11}$ (Picture 1). The tympanomeatal flap was elevated up to annulus tympanicus, and then the annulus tympanicus was released 360 degree from sulcus tympanicus, except in the superior area of malleus bone (Picture 2). After annulus tympanicus was freed from sulcus tympanicus, the fibrous layer of tympanic membrane was lifted from tympanic membrane remnant. The fibrous layer was separated from tympanic membrane mucous layer by slowly pulling the annulus with a $90^{\circ}$ hook. (Picture 3). Inspection was conducted towards tympanic cavity, and ear bones mobility was checked, then a cut was performed to the tip of malleus bone, should the malleus tend to be too medially located. ${ }^{5,7}$ After meatotomy and freshening of margins, tympanomeatal flap was elevated circumferentially (up to the level of the fibrous annulus), except superiorly in the region of head of malleus. Canaloplasty was performed whenever required. After taking the fibrous annulus out of the bony sulcus all around, using a curved blunt hook, the fibrosquamous layer was lifted off the tympanic membrane remnants along with the annulus, leaving behind remnant of the mucosal layer. After inspecting the middle ear and the Eustachian tube opening, and checking the ossicular mobility, the tip of malleus was nibbled wherever required (in cases of medialization of handle). The patency of the aditus ad antrum was checked. Fresh temporalis fascia was then harvested, and it was then grafted in such a fashion that it rested on the remnant mucosal layer, under the malleus handle, and on the bony canal walls all around. (Picture 4). The tympanomeatal flap and annulus tympanicus was then reposited. The graft was then covered with gelfoam soaked with blood and antibiotic fluid. ${ }^{5}$
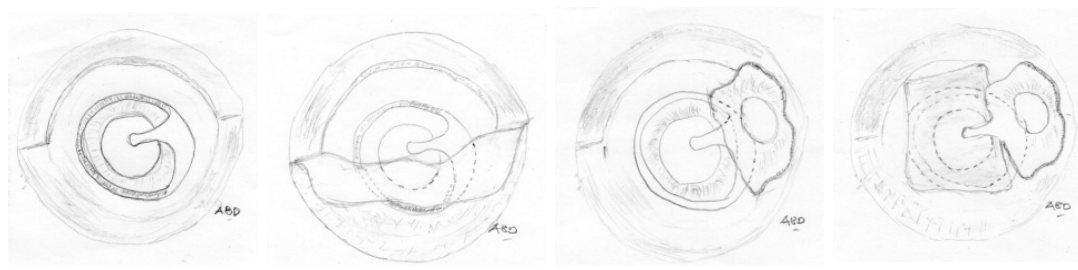

Pict.1.Tympanomeatal flap incision at $\mathbf{1 2}$ hour and 6 hour, followed by half circle cut from inferior to superior. Pict.2. Scheme of tympanomeatal flap elevation up to annulus tympanicus.

Pict.3. Scheme of tympanic membrane fibrous layer after being separated from the mucous layer.

Pict.4. Scheme of grafting the profunda part of fascia musculus temporalis. 
The next day, patient could be discharged supplied with antibiotic, decongestant, analgetic, and a medicated ointment pack was kept in the external auditory canal for 1 week. The patient was followed up on a regular basis, on the $1^{\text {st }}$ week, $2^{\text {nd }}$ week, $4^{\text {th }}$ week, $8^{\text {th }}$ week, and $12^{\text {th }}$ week. At $12^{\text {th }}$ week, a postoperative pure tone audiogram was performed to assess the hearing level.

This paper intended to report type 1 tympanoplasty interlay method to close large central tympanic membrane perforation of CSOM TT patients at Prof. Margono Soekarjo District Hospital (MSDH), Purwokerto, Banyumas, Central Java.

\section{CASE REPORT}

\section{Case 1}

Male, 39 years old, came to ENT Clinic MSDH, Purwokerto with main complaint of decreased hearing since 3 years. Patient complained of occasional ear discharge. About one year before, patient underwent left ear tympanic membrane restoration through the ear canal. Three months postoperative, the hearing problem reoccurred. Otomicroscopy examination showed a dry, large central tympanic membrane perforation, and normal tympanic cavity mucosa (no mucosal thickening) on the left ear, as shown in picture 5 .

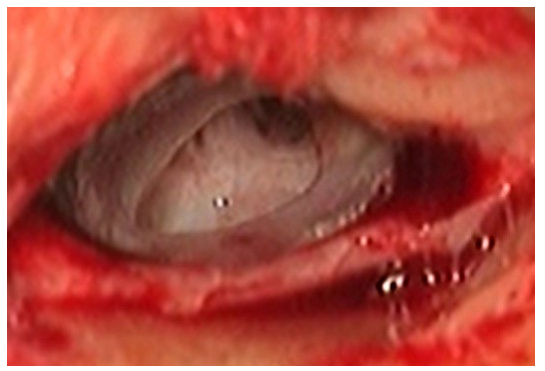

Picture 5. Dry, large central tympanic membrane perforation
Tuning fork examination, the Rinne test gave positive result, and Weber test showed lateralization to left ear. Pure tone audiometry found hearing threshold of left ear was $45 \mathrm{~dB}$ and air-bone gap (ABG) $25 \mathrm{~dB}$. Patient was diagnosed as inactive Chronic Suppurative Otitis Media, tubotympanic type (CSOM TT).

Patient underwent tympanoplasty using temporalis muscle fascia graft with interlay method technique, performed under general hypotension anesthesia. Half an hour preoperative, the patient was given prophylactic antibiotic. The procedure commenced with infiltration of a mixed combination liquid of lidocaine $2 \%$ and epinephrine $1: 100.000$ on retroauricular and on ear canal four quadrants.

The operation started with an incision made about 3-5 $\mathrm{mm}$ from retroauricular sulcus, cutting through the skin, subcutis, and periosteum; started from linea temporalis to the tip of mastoid. Tympanomeatal flap was made with incision at 12 hour and 6 hour; and from the tip of 6 hour, the incision proceeded to half circle cut from inferior to superior.

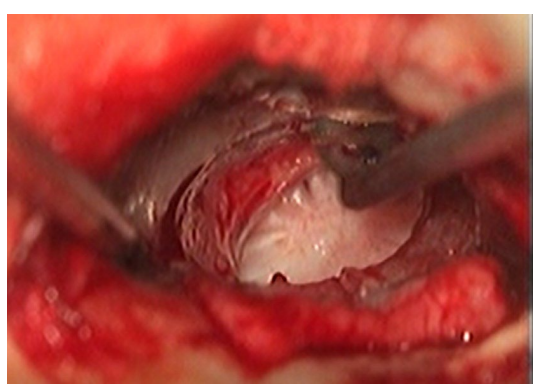

Picture 6 . Half circle incision from inferior to superior

The tympanomeatal flap was elevated up to annulus tympanicus, and then the annulus tympanicus was released 360 degree from sulcus tympanicus, except in the superior area of malleus bone, as seen in picture $7 \mathrm{a}$ and $7 \mathrm{~b}$. 


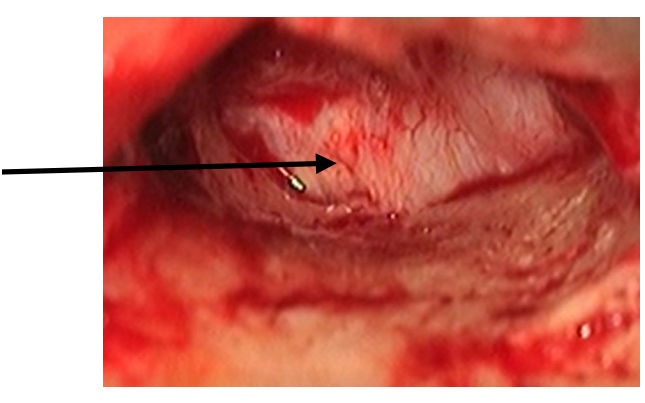

Picture 7a. Tympanomeatal flap was elevated up to annulus tympanicus

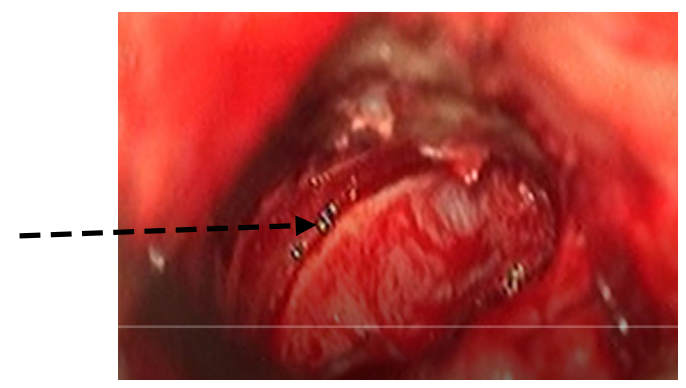

Picture 7b. Annulus tympanicus was released 360 degree from sulcus tympanicus

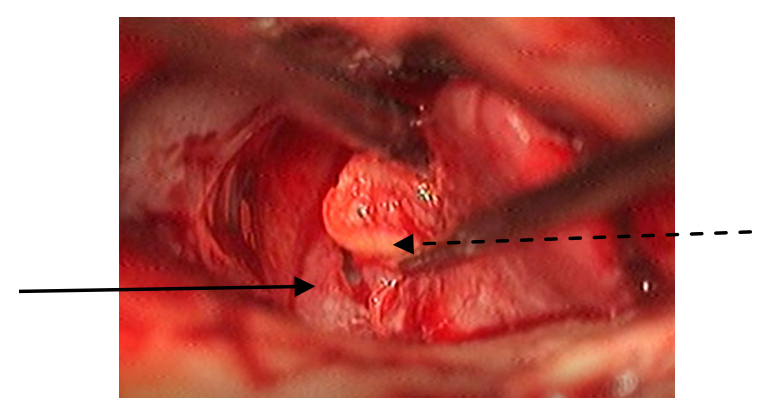

Picture 8. The dotted line showed annulus tympanicus was pulled by 90 degree hook to separate the fibrous layer from mucous layer of tympanic membrane. The straight line showed the mucous layer which had been separated from the fibrous layer

Afterwards, fresh temporalis fascia was harvested, and then grafted in such a fashion that it rested on the remnant of mucosal layer, under the malleus handle, and on the bony canal walls all around. (Picture 9)

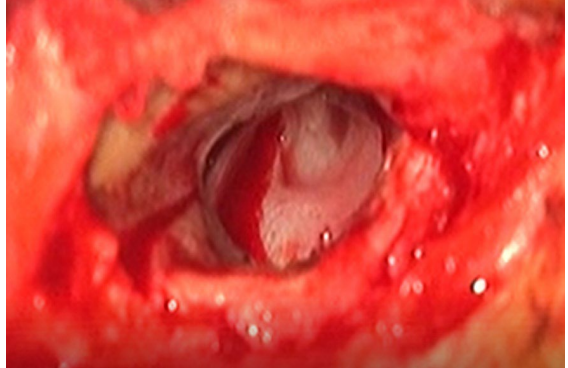

Picture 9. The graft of temporalis muscle fascia was implanted with interlay method

One week postoperative, the patient came for a follow up at MSDH ENT Clinic. The operation wound was fine, and there was no sign of infection. Patient was given antibiotic and decongestant. Two weeks postoperative, ear canal pack was taken out, and showed intact tympanic membrane and graft vascularization was good. Four weeks postoperative, tympanic membrane was intact, graft vascularization was good, and patient felt improved hearing. Then, patient was advised to do follow up every 4 weeks. At 12 weeks postoperative, tympanic membrane was intact (Picture 6), and audiometry examination exhibited a raise in left ear hearing threshold to $25 \mathrm{~dB}$ and air-bone gap became $5 \mathrm{~dB}$.

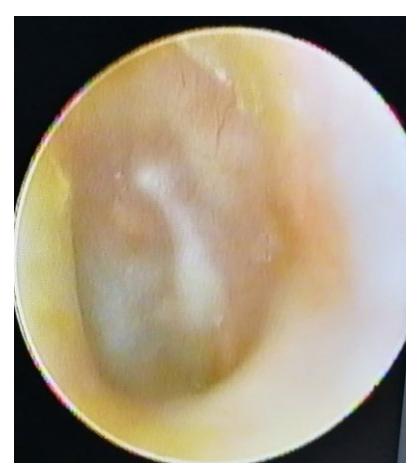

Picture 10. Otoendoscopy examination 12 weeks postoperative showed an intact tympanic membrane 


\section{Case 2}

Female, 18 years old, came to MSDH ENT Clinic with main complaint right ear hearing disturbance with occasional otorrhea for about 2 years. Since 6 months previously, the hearing loss was more notable, but there was no ear discharge. The otomicroscopic examination showed a dry, large, central, tympanic membrane perforation. (Picture 7). The tuning fork examination revealed right ear conductive deafness. Audiometric examination gave result of $43.75 \mathrm{~dB}$ right ear hearing threshold, and air-bone gap of $32.5 \mathrm{~dB}$.

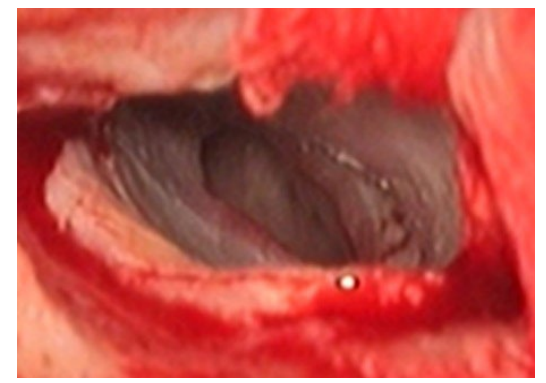

Picture 11. Dry, large, central, tympanic membrane perforation

Patient underwent type 1 tympanoplasty with interlay method. One day postoperative, patient was discharged from the hospital, supplied with antibiotic, decongestant, and analgetic. Patient was advised to do follow up one week after. During the follow up in MSDH ENT Clinic, the retroauricular postoperative wound was good, no dehiscence.

Two weeks postoperative, patient came to do follow up at MSDH ENT Clinic, ear pack was taken out from ear canal, and showed dry intact tympanic membrane with good vascularization.

At the $4^{\text {th }}$ week and $8^{\text {th }}$ week postoperative visits, tympanic membrane was intact, and patient felt an improved hearing. At $12^{\text {th }}$ week follow up, tympanic membrane was intact (Picture 8). Audiometric examination found improved hearing threshold into $21.25 \mathrm{~dB}$, and air-bone gap became $7.5 \mathrm{~dB}$.

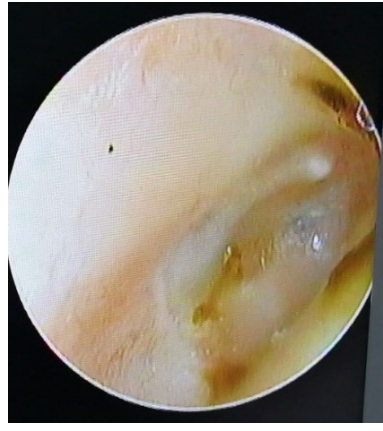

Picture 12. Otoendoscopy examination showed an intact tympanic membrane

\section{Case 3}

Female, came to MSDH ENT Clinic complaining of hearing loss in right ear. This complaint started two years previously, occurred with yellow thick odorless discharge. Patient had undergone a routine therapy by an ENT Specialist, and no more fluid discharge on right ear for seven months. Otomicroscopy examination found a dry, large, central perforation of tympanic membrane. (Picture 13). The tuning fork test revealed right ear conductive deafness. Patient's audiogram showed a hearing threshold of right ear was $46.25 \mathrm{~dB}$ and air-bone gap was $27.5 \mathrm{~dB}$.

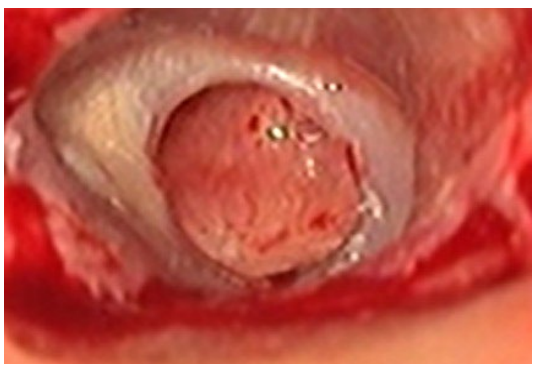

Picture 13. Dry, large central tympanic membrane perforation

Type 1 tympanoplasty interlay method was performed to close the perforation. One day postoperative, the patient was discharged from the hospital, supplied with antibiotic, decongestant, and analgesic. Patient was advised to do follow up at $1^{\text {st }}$, 
$2^{\text {nd }}, 4^{\text {th }}, 8^{\text {th }}$ and $12^{\text {th }}$ week postoperative. In the $1^{\text {st }}$ week, patient came for a follow up, postoperative wound healed, no infection in the area. Ear pack was taken out at the $2^{\text {nd }}$ week postoperative follow up. The tympanic membrane looked intact, dry, with good vascularization. Patient felt an improved hearing. In $4^{\text {th }}$ and $8^{\text {th }}$ week postoperative follow ups, patient felt improved hearing, and no other complaint. Otoscopy examination found an intact tympanic membrane.

In $12^{\text {th }}$ week postoperative follow up, she felt her hearing back to normal, and otoendoscopic examination found an intact tympanic membrane with good vascularization. (Picture 14). Audiometric examination of right ear found a normal range hearing threshold of $23.75 \mathrm{~dB}$ and air-bone gap of $7.5 \mathrm{~dB}$.

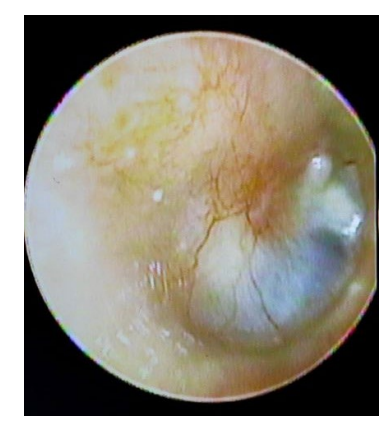

Picture 14. Otoendoscopy examination 3 months postoperative presented an intact tympanic membrane with good vascularization

\section{CLINICAL QUESTION}

"Does interlay method type 1 tympanoplasty performed on large central tympanic membrane perforation provides better result compared with other methods of type 1 tympanoplasty?"

\section{REVIEW METHOD}

Literature search was performed with keywords "Chronic Suppurative Otitis Media" AND "interlay tympanoplasty"
AND "underlay tympanoplasty" AND "large central perforation".

\section{RESULT}

The result of literature search in database Cochrane, Pubmed, and Google Scholar obtained 3 literatures which were published in the last 10 years, relevant with the topics and the complete academic scripts were available.

\section{DISCUSSION}

Patil et al. ${ }^{5}$ did an evaluation on 100 inactive Tubotympanic (TT) Chronic Suppurative Otitis Media (CSOM) patients who underwent interlay technique type 1 tympanoplasty, with a success rate of $96 \%$. The mean air-bone gap (ABG) preoperative was $36,42 \pm 12,01 \mathrm{~dB}$, and postoperative was $9.7 \pm 6.71 \mathrm{~dB}(\mathrm{p}<0,001)$. This result had shown a significant difference of the $A B G$ before and after surgery.

Jain et al. ${ }^{7}$ studied 500 cases of TT CSOM, dry for at least 6 weeks, who underwent interlay technique type 1 tympanoplasty, and reported a success rate of $96.6 \%$. The hearing improved with the mean postoperative ABG reducing to $10.12 \pm 5.84 \mathrm{~dB}$.

Other study in Egypt by El Feky et al. ${ }^{12}$ on 20 TT CSOM patients with large central tympanic membrane perforation who underwent interlay technique type 1 tympanoplasty, achieved a success rate of $90 \%$ of closing the perforation. The improved mean of ABG pre-operative was $23.2 \pm 7.1 \mathrm{~dB}$ became 11.4. $.3 .9 \mathrm{~dB}$ with $\mathrm{p}<0.001$.

Type 1 tympanoplasty is a surgical ear procedure which is very often practiced and, is only for tympanic membrane perforation without any ear bone damage. ${ }^{6}$ A successful tympanoplasty is assessed from: a) graft integrity; b) improved postoperative hearing threshold or hearing gain; and, c) no atelectasis nor secretory otitis media. ${ }^{5,8}$ 
Since the first time introduced by Komune et al. ${ }^{13}$ in Japan 1992, the interlay method had a high success rate of $94.2 \%$. Other study by Hay and Blanshard, ${ }^{11}$ in England 2009 showed a success rate of interlay tympanoplasty as high as $91 \%$. In India, several researchers who implemented interlay tympanoplasty had achieved a success rate of $93.3 \%$ as performed by Kumar et al. ${ }^{10}$ in 2016, and Chandra, et al. ${ }^{8}$ in 2017.

Kawatra et al. ${ }^{14}$ had compared the three methods of graft placing in tympanoplasty i.e. overlay, underlay and interlay. The result of his study exhibited the percentage of success rate of overlay method was $83.3 \%$, underlay $86.67 \%$, and interlay achieved $93.3 \%$. Several studies's result had shown that interlay method was a very promising method for closing large tympanic membrane perforation.

The most beneficial and important value of the interlay method was a remarkable faster epithelization compared to other methods. ${ }^{12}$ Several other benefits of interlay method are: a) There were no anterior canal wall blunting as the fibrous annulus which was elevated during the procedure was meticulously placed back onto the bony annulus all around and secured with small pieces of gelfoam, b) no lateralization because the graft was placed in medial side of malleus bone and fibrosquamous layer of tympanic membrane; c) no chance of epithelial cysts nor iatrogenic cholesteatoma formation because the fibrosquamous layer of tympanic membrane was totally removed, leaving no residual epithelium behind; d) no medialization due to the graft was in lateral side of the mucous layer of tympanic membrane; e) myringitis due to endothelium overgrowth on the graft could be avoided; and f) no reduction in the middle ear space. ${ }^{5}$ The weakness of interlay method was: a) relatively more difficult than underlay and overlay methods; b) took more time to perform; and, c) required a skillful experienced operator. ${ }^{6,8}$

During executing interlay method type 1 tympanoplasty, using hypotension anesthesia is advisable to prevent blood covered visualization. Canaloplasty was performed when the bone of external canal protruded blocking visual field towards tympanic membrane. Canaloplasty was easier to be executed because the tympanomeatal flap was already circumferentially lifted, thus, no chance of tearing the tympanomeatal flap. ${ }^{5}$ The critical point of doing interlay method was during releasing annulus tympanicus from sulcus tympanicus circumferentially, and while separating the fibrous layer from the mucous layer of tympanic membrane. This should be carried out with utmost care and gently, so that annulus tympanicus was not torn. If the annulus was broken, the integrity of tympanic membrane was disrupted, which in the end would disturb the sound conduction process. ${ }^{5,15}$

Three patients came to MSDH ENT Clinic, Purwokerto, Central Java with hearing disturbance. Clinical examination found tympanic membrane perforation $>50 \%$, and the audiometric examination showed intermediate level conductive deafness. All three patients were diagnosed as safe type inactive chronic suppurative otitis media. All three patients underwent interlay method type 1 tympanoplasty without mastoidectomy, as the anamnesis revealed more than three months dry ears, and also from the otomicroscopic inspection showed no secretion in the tympanic cavity. This was complying with the study of Kim et al. ${ }^{16}$ which stated that tympanoplasty without mastoidectomy was effective for dry safe type inactive CSOM.

Postoperatively, all three patients underwent follow up in the $1^{\text {st }}, 2^{\text {nd }}, 4^{\text {th }}, 8^{\text {th }}$, and $12^{\text {th }}$ weeks. The otoscopy examination in $12^{\text {th }}$ week found intact tympanic membrane and the audiometric examination revealed 20-25 $\mathrm{dB}$ increase of hearing threshold.

From all of these results, interlay method type 1 tympanoplasty could be considered as a good alternative for closing large central 
tympanic membrane perforation in dry safe type inactive CSOM.

\section{REFERENCE}

1. World Health Organization. Chronic Suppurative Otitis Media, Burden of Illness and Management Options, WHO Child and Adolescent Health Department, Prevention of Blindness and Deafness. Geneva. 2004.

2. Matsuda Y, Kurita T, Ueda Y, Ito S, Nakashima T. Effect of tympanic membrane perforation on middle-ear sound transmission. J Laryngol Otol. 2009; 123(Suppl. S31): 81-9.

3. Mudry A. History of myringoplasty and tympanoplasty type I. J Otolaryngol-Head and N. 2008; 139: 613-4.

4. Sergi B, Galli J, De CorSo E, Parrilla C, PaluDetti G. Overlay versus underlay myringoplasty: report of outcomes considering closure of perforation and hearing function. Acta Otorhinolaryngol Ital. 2011; 31: 366-71.

5. Patil BC, Misale PR, Mane RS, Mohite AA. Outcome of Interlay Grafting in Type 1 Tympanoplasty for Large Central Perforation. Indian J Otolaryngol Head Neck Surg. 2014; 66(4): 418-24.

6. Subramanya BT, Lohith S, Sphoorthi B. Interlay myringoplasty: hearing gain and outcome in large central tympanic membrane perforation. Trop J Ophth Otolaryngol. 2018; 3(3): 51-6.

7. Jain S, Gupta N, Gupta R, Roy A. Interlay Type I tympanoplasty in large central perforations: Analysis of 500 cases. Indian J Otol. 2017; 23: 32-5.

8. Lee HY, Auo HJ, Kang JM. Loop overlay tympanoplasty for anterior and subtotal perforations. Auris Nasus Larynx. 2010; 37: 162-6.

9. Heung-Yeup Lee, Hyeon-Jin Auo, JunMyung Kang. Loop overlay tympanoplasty for anterior and subtotal perforations. Auris Nasus Larynx. 2010: 37: 162-6.

10. Kumar G, Sharma R, Shakeel M, Jassal SS. Interlay Myringoplasty: Hearing Gain and Outcome in Large Central Tympanic Membrane Perforation. Orissa J Otolaryngol Head Neck Surg. 2016; 10(11): 42-8.
11. Hay A, Blanshard J. The Anterior Interlay Myringoplasty: Outcome and Hearing Results in Anterior and Subtotal Tympanic Membrane Perforations. Otol Neurotol. 2014; 35: 1569-76.

12. El-Feky AEDM, Abdelmaksod MK, Mohamed SAM, Aldaem RYRA. Interlay Technique Tympanoplasty: Surgical Difficulties with Variable Grafts. Zagazig Univ Med J. 2019; 25(4): 539-47.

13. Komune $\mathrm{S}$, Wakizono S, Hisashi K, Uemura T. Interlay method for myringoplasty. Auris Nasus Larynx. 1992; 19(1): 17-22.

14. Kawatra R, Maheshwari P, Kumar G. A Comparative study of the techniques of Myringoplasty - Overlay Underlay \& Interlay. IOSR J Dent Med Sciences. 2014; 13(12): 12-6.

15. Kassem F, Ophir D, Bernheim J, Berger G. Morphology of the human tympanic membrane annulus. Otolaryngol Head Neck Surg. 2010; 142: 682-7.

16. Kim H, Bae HY, Choo OS, Choung YH. Efficacy of Tympanoplasty Without Mastoidectomy for Treating Chronic Otitis Media in Patients with Mastoid Cavity Opacification in Temporal Bone Computed Tomography Findings. Clin Exp Otorhinolaryngol. 2018; 11(1): 30-4. 